\title{
The Gradual Erosion of the Social Security Function of Customary Land Tenure Arrangements in Lineage-Based Societies
}

\section{Jean-Philippe Platteau*}

February 2002

\begin{abstract}
Customary rules governing access to land and other natural resources in village societies have characteristics that allow them to fulfil social security functions and achieve equity objectives. This is true of both common-property resources and land parcels held under individualized tenure. However, when land pressure increases under the combined influences of population growth and market integration, a shift occurs from extensive to intensive resource use patterns. As a result, the efficiency costs of erstwhile equity- and insurance-oriented arrangements rise, thus forcing them to evolve significantly. In particular, land tenure arrangements undergo a major transformation towards more individualized forms with the consequence that property rights in land are increasingly defined without regard for equity and insurance concerns.
\end{abstract}

Keywords: land tenure, informal insurance, equity, common property

JEL classification: O13, O17, Q15

Copyright (C) UNU/WIDER 2002

*Centre de Recherche en Economie du Développement (CRED), Department of Economics, University of Namur

This study has been prepared within the UNU/WIDER project on Insurance Against Poverty, which is directed by Dr Stefan Dercon.

UNU/WIDER gratefully acknowledges the financial contribution to the project by the Ministry for Foreign Affairs of Finland. 
UNU World Institute for Development Economics Research (UNU/WIDER) was established by the United Nations University as its first research and training centre and started work in Helsinki, Finland in 1985. The purpose of the Institute is to undertake applied research and policy analysis on structural changes affecting the developing and transitional economies, to provide a forum for the advocacy of policies leading to robust, equitable and environmentally sustainable growth, and to promote capacity strengthening and training in the field of economic and social policy making. Its work is carried out by staff researchers and visiting scholars in Helsinki and through networks of collaborating scholars and institutions around the world.

UNU World Institute for Development Economics Research (UNU/WIDER)

Katajanokanlaituri 6 B, 00160 Helsinki, Finland

Camera-ready typescript prepared by Jaana Kallioinen at UNU/WIDER

Printed at UNU/WIDER, Helsinki

The views expressed in this publication are those of the author(s). Publication does not imply endorsement by the Institute or the United Nations University, nor by the programme/project sponsors, of any of the views expressed.

ISSN 1609-5774

ISBN 92-9190-170-9 (printed publication)

ISBN 92-9190-171-7 (internet publication) 


\section{Introduction}

In our 1991 paper 'Traditional Systems of Social Security and Hunger Insurance: Past Achievements and Modern Challenges', published under the WIDER programme of Studies in Development Economics (Platteau 1991), the need had been emphasized to distinguish between two central mechanisms of social security in traditional village societies, namely voluntary state-contingent reciprocal transfers and access rules for vital resources. While the first of these mechanisms has received considerable attention in the economic literature, the second one has been largely ignored. To what extent rules of access to vital resources can be considered as an effective way to cope with adverse shocks is a pending question that will need to be elucidated.

Evidence indicates that informal mutual insurance arrangements are an imperfect mechanism of social security. Not only have they a restricted scope, but they are also fragile, unreliable in protecting the poorest households, and susceptible of retarding capital accumulation and economic growth (Platteau 1991, 2000: ch. 5, Alderman and Paxson 1992, Morduch 1995). As regards the first point, from the observation that reciprocal transfers are frequent it is not legitimate to infer that they provide effective insurance to villagers. For one thing, such transfers may involve only a limited fraction of the village population and, for another thing, they may represent only a low proportion of the income shocks in bad periods (Rosenzweig 1988, Fafchamps et al. 1998, Cox and Jimenez 1990, 1997, Platteau 1997, Goldstein 1999). Risk characteristics are an important determinant of the feasibility of group - or community - based informal insurance. Thus, low frequency events as well as repeated shocks (shocks strongly correlated over time) and covariate risks are difficult to insure against on a local level. This observation carries the unfortunate implication that informal village mechanisms may be particularly fragile when needed most (Morduch 1999).

More importantly, the effectiveness of informal risk-sharing schemes is likely to decline as economic mobility and differentiation increase with development. As a matter of fact, widening wealth differentials, say, as a result of newly emerging outside incomeearning opportunities, create incentives for the better-off households to leave the risksharing scheme. As they exit, the welfare gains from the scheme to those remaining in the system fall, and it can unravel (Fafchamps 1992, Hoff 1997).

In the present paper, we intend to argue in the same vein that the effectiveness of the second mechanism is also subject to erosion under the impact of economic development and population growth. Public intervention from central agencies is therefore all the more justified as market development is more advanced. In Section 1, the operation of the customary rules of access to vital resources is described. Also, their potential role as a social security mechanism is subsequently discussed, carefully distinguishing between social security for the poor in the sense of protection against the risk of chronic poverty, on the one hand, and insurance against adverse shocks, on the other hand. Section 2 is the central part of the paper where attention is drawn to the dynamic evolution of these rules as the value of land and water resources increase as a result of economic development and population growth. As for Section 3, it will summarise the main findings and draw policy implications. 


\section{Customary rules of access to vital resources and their role as social security provider}

\subsection{Central features of the customary system of land tenure}

Under the traditional land tenure system in Africa and other regions with a long tradition of extensive land use patterns associated with high land-man ratios, land and other natural resources are held under a system of corporate ownership. This implies that the right to allocate land is vested in the heads of collectives, which claim to be its ultimate rightful owners, typically ward, or village chiefs, earth priests, masters of fire or masters of the axe. The general principle is that a member of the group or community is entitled to be allocated land for cultivation. The term 'member', it must be pointed out, includes not only those who can claim descent, actual or putative, from the founding lineages but also strangers and migrants who have been accepted as members of, and reside with, the group (Popkin 1979: 43, Noronha 1985: 182). Yet, access to land may be unequal as it is usually qualified by rules relating both to the period of residence in the area and the member's ancestry: thus, members who are recent residents are likely to be entitled only to marginal lands while those who can trace back their ancestry to the founders of the village often get the best lands (whenever they are in scarce supply) or parcels of greater size (Noronha 1985: 182). 1

It must moreover be pointed out that the relationship between membership and access to land is reciprocal: on the one hand, group membership is the basis of social rights and, on the other hand, access to a share of the corporate productive assets serves to validate membership in the group (Berry 1984: 91). The latter holds especially true for members of late arrived kin groups who have to obtain prior authorization of local land authorities to have access to land (Breusers 2001: 54-8). Such authorization is refused or withdrawn only when the 'stranger' behaves incorrectly, typically when he violates the local rules and traditions.

As a matter of principle, the land that a group member is allowed to receive from the community to which he belongs must be sufficient to provide for his own livelihood and that of his family (see, e.g. Cohen 1980: 353). In such a need-based logic, since the size of the family is subject to fluctuations over the life cycle, the size of the land allotted to the head of a household must also be susceptible of being adjusted. In Lesotho, for example, till recently, 'village chiefs had the power to acquire lands deemed surplus to

1 Among the Moose of the North-Central region of Burkina Faso, we learn that, "if a "stranger" obtains high yields or if rainfall circumstances during the past seasons favoured for example farming on lowland, the (low) land can be withdrawn for use by a tengbiiga [that is, an elder of the village's founding kin group]' and the 'stranger' 'will be asked to choose another plot to farm in the village territory' (Breusers 2001: 56). The point of the matter is that, in the village's hierarchy of control and access rights to land, relative 'strangers' occupy a low position. This is reflected in the fact that they are entitled only to land not wanted by any member of an earlier arrived kin group [ibidem: 58-60]. It is actually inconceivable that a 'stranger' fares better, in the long run at least, than a member of the autochtonous population. Still, it remains possible for latecomers to gradually enlarge their claims over local plots through prolonged presence and use of the land - 'Consolidating their presence at a particular place is their only way to ever root territorially in the village' - and through ritual collaboration and the establishment of kin relations with founding lineages [ibidem: 60-2]. Breusers uses the expression autochtonization to characterize this process of gradually securing tenure rights in a village in which a kin group has been a latecomer. 
requirements of a household and redistribute these among the more needy members' (Noronha 1985: 186). Likewise, in the villages of Niger, there exists a pool of community land entrusted to the village chief, known as hawjou land, which he has the right to put at the disposal of farmers who are short of land (Gavian and Fafchamps 1996). Another principle that follows from the need-based logic of land allocation is that the allottee has possession and use of the lands only as long as they can be cultivated with the help of the family workforce (Noronha 1985: 183). None the less, a man is entitled to keep some land for his sons if they are old enough to establish themselves as heads of their own families within the next few years. If he abandons his fields permanently, the land reverts to the ward or the tribe' (Schapera 1943: 44, Ault and Rutman 1979: 170).

It is therefore evident that a guaranteed access to land and other natural resources is a 'general right' granted to all members of the group as distinct from the 'specific rights' to a particular portion of the resource. While the former is 'an inseparable element of the status as member of the tribe' and can only be lost through formal expulsion from the group, the latter can be reshuffled according to circumstances. For instance, in a system of slash-and-burn agriculture, when the period of fallow is so long that all traces of previous cultivation are lost, a household does not automatically return to the same parcel (Boserup 1965: 79-80, Ault and Rutman 1979: 172).2

In many instances, it must be noted, different types of tenure coexist in the same location, a feature known as multiple tenure that results from the presence of lands of varying quality and therefore subject to varying modes of exploitation. Leaving aside common-property lands, such as grazing lands, to which we shall soon return, we find, at one extreme, the intensively cultivated garden lands situated near dwellings and over which households have close to permanent rights and, at the other extreme, lands devoted to slash-and-burn cultivation over which rights granted are only temporary, as explained above 3 In addition, unlike what is observed in more developed agricultural societies, rights over land are usually not exclusive, meaning that various overlapping rights may prevail over a given portion of the community territory. This is especially noticeable in the case of societies that combine agriculture and grazing: it is indeed a common practice that farmers open their fields after the harvest so that herder groups or other farmers including themselves can feed their cattle on the remaining stubble. In such circumstances, the definition of tenure rights varies through time (see, e.g. Cohen 1980, Dahlman 1980, Noronha 1985, Platteau 1992).

2 By abandoning land under cultivation, an individual actually forsakes his right to cultivate it. This is a rational step to take so long as the net return from newly cleared land exceeds the net return from cultivating previously cleared land. This happens when the fertility of the land has been exhausted and 'is restored by allowing the land to remain fallow while newly cleared land is cultivated' (Ault and Rutman 1979: 172).

3 In Bechuanaland (presently Botswana), for example, the chief, with the support of the tribal assembly and the notables (among whom the headmen of 'wards' figure prominently), acts as a trustee for his tribe. He determines 'what land shall be used for dwellings, for grazing, for cultivation, and what land shall be temporarily or permanently withdrawn from usage; also, what land shall be used in common by the tribe and what should be parceled out for use to families. The land to be distributed is allocated to the wards, and the headmen of the wards then assign the plots to individuals. From the headman every married man in the ward can claim enough land for residence and cultivation to accommodate his family. Once land has been taken for cultivation, the family to which it has been assigned remains in possession as long as it continues the use' (Landauer 1964: 497, quoting Schapera 1943: 44). 
The same principles essentially apply to herder societies as well: in particular, members are entitled to own a stock of animals deemed sufficient for subsistence and, when any of them falls into destitution, he can rely on his community to have his ownership position restored and thus escape the poverty trap. In Somali traditional pastoral communities, for example, poor or destitute individuals (known as maskiin or ceer) are given a collection of animals by members of their lineage (the reer) so that they can reenter the pastoral economy as full-fledged owners (Nunow 2000: 151).

As regards access to land for women, the guiding principle in (patrilineal) lineage-based societies is that women can have only use rights over the land. Upon marriage, they are typically expected to work some part of their husband's land, and their degree of autonomy varies considerably according to whether they work on a family (collective) field, on a husband's field, or on a parcel specially earmarked for them. In the latter case, women enjoy most autonomy, particularly under the form of the right to freely dispose of the land's produce. Nevertheless, even when working on their own fields, women remain placed under the authority of their husband acting as household head. This is notably reflected in the fact that the time schedule of women's work is laid down by the husband and, when they have access to a woman's plot (which is not necessarily true), it is usually during the hottest time of the day (in the afternoon) that they are allowed to work on it.

In the event of separation or divorce, the rule is that women have the right to return to their native village where they are granted use rights over the family land, or are accommodated in the farm of a close relative (father, brother or uncle). This is with a view to ensuring their livelihood until they hopefully find a new husband. Of course, when the woman is deemed responsible by her family for the marriage break-up, acute pressure is exercised to drive her back to her husband and intense efforts are deployed to reconcile the couple. It is only when a woman has been chased away by her husband or when she has left him but the fault is clearly on the husband's side -generally on account of impotency or ill-treatment of his wife- that she has an automatic right to go back to the parental farm.

In the case of the death of her husband, a widow is neither abandoned nor denied access to land. Depending on the circumstances, she will either remain on the husband's land (in the case she accepts a levirate marriage or is old enough to have grown-up children to take care of her), or go back to her father's farmland and draw her livelihood from it as long as necessary to find a new husband. As for unwed mothers, they also have the right to stay on the parental land during the time needed for them to find a man willing to marry them and take charge of their child or children.

As our own field studies in Senegal (in the Senegal river valley) and Burkina Faso (various districts) have shown, the aforementioned mechanisms of women's social protection are still well alive in West Africa (see Abraham and Platteau 2001).

\subsection{The village commons}

We have so far considered situations in which land is parcelled out among household units for cultivation purposes. In actual fact, some portion of the natural resource endowment of a tribal community's is typically kept as a commons to which every member has an automatic right of access. Common property resources are usually 
resources the division of which would involve high transaction costs (highly spread out resources, possibly of a rather low quality), or the returns to which are highly variable across time and space. In the latter case, indeed, assuming that the probability distributions are not correlated too much across spatial groupings of land or water and that they are not overly correlated over time, a system offering access to a large area within which rights-holding users (think of herders or fishermen) can freely move appears as a desirable arrangement from a risk-reducing perspective (Dasgupta 1993: 288-9, Baland and Platteau 1998, Platteau 2000: ch. 3, Breusers 2001).4

Village commons can be used either on a permanent (a) or a transient basis (b); and it can be used either by the poor $(\alpha)$ or by all members of the community $(\theta)$. To begin with (case $\mathrm{a} \theta$ ), the commons may well form a vital resource that everybody depends upon for everyday livelihood (and not only for 'bad' times), such as happens when a resource is maintained under the common property regime because it is costly to divide and/or is unpredictable (in the sense that its value has a large variance per unit of time per unit area). As pointed out above, when the resource is highly unpredictable and spatially spread (think of semi-arid scrublands and grasslands, for example), the fact that it is kept whole and managed collectively also enables villagers to stabilise their incomes across environmental variations. In this case, the insurance function of the commons is patent.

Second, the commons may serve as a fallback resource that provides all members with partial protection in times of unusual economic stress (case $b \theta$ ). To the extent that risks are idiosyncratic rather than collective, it is important that people in the community are left free to access the commons depending upon their needs of the moment. In such conditions, the absence of exclusive property rights means that risks are more effectively pooled (Bromley and Chavas 1989: 730). Note that in this case the more aggregate the risks, or the more common the (downside) shocks hitting the community, the larger the externalities created in the use of the commons and the lower the (average) return extracted by the villagers.

Third, it is an oft-noted feature of common-property resources that they entail most benefits for the poor who do not have as attractive alternative income-earning opportunities as the richer members of their community (case a $\alpha$ ). Studies conducted in other continents than Africa indeed show that poor members of rural communities tend to derive a substantial fraction of their incomes from the village commons, which then have a clear social security function in the sense of providing protection against the risk of chronic poverty (Jodha 1986, McKean 1986, Dasgupta 1987, Hecht et al. 1988, Humphries 1990, Agarwal 1991).

Finally, it may be the case that it is mainly under adverse shocks that the recourse to the commons' produce is likely to prove most critical to the survival of the poor. In this case $(b \alpha)$, insurance against the risk of transient poverty is provided to this category of people.

4 Note that parcelling out the resource could apparently solve the above problem if users would have access to a wide portfolio of resource patches with different ecological characteristics. The problem, however, is that such a solution would be prohibitively costly to enforce as it is obviously difficult to monitor individualized rights over such highly dispersed and infrequently visited resource patches. The high unpredictability of a resource's returns is therefore not sufficient to account for common property: it must be complemented by the high exclusion costs of a spread resource base (Platteau 2000: 88). 


\subsection{Land loans and non-land exchange arrangements}

Clearly, village commons can be effective not only in helping the vulnerable members of the community to escape chronic poverty, but also in helping them and probably other members of the community to tide over periods of unusual economic stress. The first function is equally evident in the case of privately appropriated land (or water) resources in so far as a corporate system of land ownership guarantees an access to portions of these resources that enables all member households to earn a decent livelihood in different phases of their lifecycle. Whether such a system allows people to cope with adverse shocks in the short or medium term will depend on the presence of other institutional arrangements. Indeed, because land is not the only factor that plays a critical role in production, a guaranteed access to land does not properly insure a household or a person confronted with a sudden shortage of a complementary input. Just consider the case of a dearth of labour; say due to illness or a temporary absence from the village. In this case, customary land tenure rules must be complemented by labour exchange mechanisms in order to provide effective protection against income shortfalls. In actual fact, the supply of emergency labour assistance to a needy household within the framework of voluntary reciprocal transfers (in kind) is frequently observed in tribal communities.

What applies to labour also holds true for other production factors such as draught animals: in order to allow a field to be cultivated even when the possessor has lost his cattle, neighbours can possibly come to his rescue by bringing their own animals to that field. Since well-known moral hazard considerations prevent them from simply lending their stock to the needy farmer, assistance is here provided in the form of a joint input associating labour with draught power.

If the risk lies in a shortage of land rather than labour or cattle, the customary system of land tenure can be considered to effectively perform as a social security mechanism provided that land adjustments are rapid enough. The above-described rules that apply to women who find themselves without the support of a man are a good illustration of this possibility. Also, as pointed out by Boserup: 'If a family does not need to use a given plot for a certain period it may pledge it to another family... subject to the condition that the land must be returned upon request' (Boserup 1965: 80). In other words, the operation of a flexible system of land loans or pledges usually provides the necessary safeguard against short-term imbalances in land distribution. Among the Chagga and the Kikuyu (Kenya), for example, 'tenants' could be accepted on lineage land, and they used (before registration of land was undertaken towards the end of the colonial period) to pay a fee up front for use of the land. The lineage could redeem the land at any time by repaying the original amount, but the redeemer had to reimburse the tenant for any improvements made to the land (Pinckney and Kimuyu 1994: 12, see also Schapera 1943).

Long-term loans of land can also be observed if this resource is unequally distributed because villagers belong to different ethnics, castes, lineages, or family units that are unequal in social status (think, for example, of the persisting social differentiation between descendants of slaves and slave owners in West Africa, which dates back to the Islamic conquest). Traditional land loans can sometimes extend over several generations, thus reflecting the existence of patronage relations through which land-rich households put at the secure disposal of land-poor households the amount of land necessary for their subsistence. Typically, in such cases, land borrowing and lending 
transactions, at least among native farmers, are often part of a wider relationship between two families or lineages, and the desire to keep such a relationship going ensures that borrowing arrangements are frequently renewed or not easily ended.

For instance, as has been observed in the particular case of Burkina Faso by Matlon (1994) and De Zeeuw (1997), use rights over borrowed lands can actually be bequeathed to descendants when the borrower and the lender have struck a sort of longterm socio-political alliance (the borrower owes loyalty to the family of the lender) and land has thus been lent for an indefinite period. In the words of Matlon:

Because of the strong tradition of transfer of intergenerational use rights, inheritable use rights prevail even for fields on long-term borrowing arrangements [borrowed by ancestors and subsequently passed down to current users through inheritance]... Most farmers consider withdrawal of use rights unthinkable for long-term borrowings that have been within the current user's household for more than one generation (Matlon 1994: 52-4).

Nowadays, this long-term borrowing of land (traditionally known as mokwala doudou) has become rather rare owing to the growing scarcity of land. It is to these kind of dynamic considerations that attention is turned in the following section.

\subsection{Summary}

Before turning our attention to dynamic processes, let us pause for a moment in order to relate the above facts to the central theme of the chapter. The customary land tenure system prevailing in lineage-based societies appears to be guided by both insurance and equity considerations. The insurance motive is evident from the fact that membership in a rural community automatically ensures proper access to land be it in the form of use rights over privately apportioned land plots or over the village commons. Thus, for instance, a member who emigrated and later decides to return to his native village because of economic difficulties or other reasons is entitled to obtain enough land to make a living.

As for the equity motive, it is reflected in the fact that, for example, people with smaller privately held landholdings have the same rights of access to the village commons than those with large landholdings -and may actually use them more intensively than the latter. Equality is not necessarily perfect, though, since descendants of the founding lineage(s) are generally guaranteed a better access to valuable lands. What deserves to be emphasized is that the efficiency costs of redistributive or insurance-motivated rules of land allocation are nil or negligible. When land use patterns are extensive, indeed, the need for land improvements simply does not exist as a result of which no particular advantage would be derived from the granting of permanent rights over well-delimited parcels of land. 


\section{The gradual erosion of the social security function of indigenous land tenure arrangements}

When population grows rapidly and when market integration proceeds at a significant pace, such as we have observed in Africa especially during the postcolonial period, land becomes more scarce and therefore more valuable. This new situation is bound to cause substantial transformations in the indigenous system of land tenure. In point of fact, observation of evolving arrangements in many African regions amply confirm the economic prediction that the nature of property rights in land must change in the direction of increased privatization and allocation processes must increasingly resemble market mechanisms (see Platteau 2000: chs 3-4, for detailed references). In the following, we intend to elaborate upon the dynamics of this evolution, especially with a view to highlighting its impact on the traditional role of land tenure arrangements as a provider of social security.

Our analysis proceeds in three successive stages where three different effects of land tenure evolution are being discussed. These effects are taken up separately in each of the following sub-sections. In the order of their presentation, they are: the growing incidence of exclusionary practices, including the collapse of social security through land access rules for single adult women (Section 2.1); the gradual disappearance of the village commons as well as their diminishing role as fall-back options for the poor (Section 2.2); and the increasing individualization of land tenure rights (Section 2.3).

\subsection{The growing incidence of exclusionary practices}

When population pressure on village-level natural resources intensifies, growing competition causes an increasing incidence of externalities among users that get reflected in declining individual incomes. A common response to this situation consists of restricting access by outsiders to these resources (see, e.g. Noronha 1985, Downs and Reyna 1988, Bassett and Crummey 1993, Berry 1993, Laurent et al. 1994). Thus, for example, in the case of the Orma pastoralist communities of northeastern Kenya, elders responded to increasing land pressure by prohibiting nomadic (Somali and other Orma) herders from grazing their herds on the village common pasture. Over the years, they strengthened this prohibition by gradually extending the period during which the local common pasture is made inaccessible to outsiders. Eventually, the restricted zone was declared out of bounds to the outsiders year round. Interestingly, however, Orma villagers continued to use the common pasture as much as they liked and this lack of restrictions applied to insiders was not seen by them as problematic in spite of the quick degradation of the resource that ensued (Ensminger 1990: 667-9).

Exclusion takes place not only with respect to common-property resources but also with respect to individually held portions of land. Thus, an immediate upshot of the growing scarcity of land is that stranger farmers are being increasingly denied their rights of access to land, especially to plots of relatively high quality. In the Senegal river valley, for example, the local Haalpulaar (Toucouleur) communities have become concerned that land will not be available in sufficient amounts for their children and grandchildren. As a result, they have started closing access to the good inundable lands (known as waalo) located near the river for all strangers and immigrant farmers, confining them to the poor-quality drylands (the jeeri soils) which are still plentiful (Rodenbach 1999). Similar events have occurred in many places in sub-Saharan Africa and violent conflicts 
have resulted in not a few cases (like in Côte d'Ivoire, in the Senegal River valley, in Guinea, in the Kivu State in Congo etc.).

Another form of exclusion that is increasingly resorted to is the calling into question of the secondary or derived rights of access to land that are usually reckoned under the customary system of land tenure. With land becoming increasingly scarce, derived rights thus tend to be denied to secondary rightsholders for fear that they might stake ownership claims and/or simply because continuous cultivation practices are being introduced with a view to making land exploitation more intensive (see, e.g. Coldham 1978, Ault and Rutman 1979, Noronha 1985, Bruce 1986, Green 1987, Bruce and Fortmann 1989, Barrows and Roth 1989, Mackenzie 1993, Atwood 1990, Platteau 1992, 1996, 2000: ch. 4).

In West Africa, for example, gradual demarcation of parcels for cultivation in what were communal pastures previously arouses the anger of those groups such as the Tuaregs and the Fulanis who primarily depend on animal grazing for their daily livelihood (see, e.g. Lund 1998). The outcome, of course, depends upon the configuration of power relations, including possible alliances with state authorities. In actual fact, 'the farmers often have the upper hand in conflicts over pastures', and 'the extension of cultivated fields into the pastoral areas is the main trend' (Ibiden: 142, 145). Revealingly, access to grazing lands is more easily open to influential and wealthy farmers who know with whom to forge tactical alliances, how to approach and mobilize authorities, how to read a sequence of contingent opportunities, and how to use economic resources at their disposal to influence the result of an arbitration.5

Women are a special category of insiders because, even though they have been born in the village, they are destined to leave it and reside in their husband's location (at least, this is so in societies following the patrilocal system of marriage). It is therefore not surprising that they are especially vulnerable when land resources are lacking. Perceived as strangers in their husband's village and as a threatening additional claimant on family land in their native village, women tend to be rejected from every quarter when in difficulty.

Thus, in the course of a field study on the role of self-help groups in Kibera slum, Nairobi, Kenya (Abraham et al. 1998), it was observed that nearly half of the members of such groups are single women: divorced or separated women, unwed mothers, eloping women and widows. Interviews revealed that many of these women have been denied access to land, whether in the village of their husband or in their native place where the parental farm is located, and were compelled to migrate to cities and survive on precarious employment, including prostitution. Young beggars in Nairobi and other big cities are actually the children of these destitute women.

Observations in Central and Western Kenya (as well as in the Kilimanjaro region in Tanzania, and to Western Rwanda) confirm that the growing number of women falling

5 As Christian Lund points out, 'some money always change hands during an audience. Economic resources, therefore, play a central role. While the difference between a token of respect, a fee and a bribe can be difficult to discern since the gesture holds several meanings depending on the position of the "giver", the "receiver" and the "onlooking opposing litigant", money or other tangible goods are necessary prerequisites for accessing the politico-legal institutions' (Lund 1998: 161). 
into the above categories are confronted with livelihood problems owing to their inability to accede to land (Hakansson 1988, Rocheleau and Edmunds 1995, Rocheleau et al. 1994, Hunt 1996, personal field observations). Thus, brothers-in-law may harass a widow because her rights to use the land of her ex-husband and to bequeath it to her children compete with their claims on the family land assets. If she wants to escape from such a conflictual atmosphere, she may have no other solution than to migrate to a city or a plantation because a return to her parents' home may prove equally difficult due to the opposition of her own brothers.

The same opposition may be manifested by the brothers towards a sister seeking haven on the family land following the break-up of her marriage, or towards an unmarried sister with children who stays in the parental home for lack of marriage proposals. Thus, parents have generally become unwilling to accept a separated daughter back home even when she has truly suffered from living with her husband. If she refuses to return to him, she is pushed out of the family on the ground that the home of a married woman is in her husband's village and that it is the duty of a woman to put up with her husband and in-law family. In fact, marriage gifts offered to a woman, such as bed and mattress, serves to carry the point that once married she has no place in her parental home. The fact that the brideprice must be repaid to the husband's family if the woman is considered responsible for the break-up of the marriage compounds the problem still further.

Finally, the growing frequency of elopements as a result of the spreading of love marriages (girls elope with boys whom they love because the latter are unable to pay the customary brideprice) can easily lead to the same predicament as unwed motherhood. In the event of separation, indeed, women who did not go through a customary marriage find themselves in the position of unwed mothers. Moreover, if their companion dies, they will be denied any use rights over his land and their children will be barred from inheriting their father's property. On the other hand, the premature death of a cohabiting woman can lead to problems for her burial since her customary right of being buried in her husband's land can be denied when the union has not been legitimized. This is a serious problem insofar as the burial in the parent's land of married daughters, whether their marriage is legitimate or not, brings shame to the family. Therefore, such a prospect is likely to be resisted by the woman's own family that usually prefers to forego the payment of the brideprice and have the union legitimized post mortem on the basis of a symbolic marriage payment so that the customary burial ceremony can take place.

According to our informants in Kenya, marriage is becoming a problem for uneducated and unemployed daughters belonging to economically better off families that are engaged in non-agricultural activities, such as trade, business and professions. Such women have a relatively low value in the marriage market as they do not have the necessary education to find a job in the modern sector nor do they have any experience in agriculture. Thus, young men in the countryside tend to rate them low because they do not know how to till the land and manage a farm. Failure to find a marriage partner after having waited for a long period has the effect of pushing these uneducated and unemployed women into unwed motherhood or elopement.

On the other hand, due to the impossibility of returning to the parental home for help in case of marital problems, women are more and more obliged to put up with unbearable tensions within their couple and the in-law family. According to our informants from 
Tanzania, parents and close relatives keep a close watch over their married daughters and invest emotionally in young couples to make sure that conjugal conflicts do not escalate to the point of marriage breakdown. This is done by paying repeated visits to them and advising them in difficult moments.

Finally, it must be remarked that when population pressure becomes very acute exclusionary practices may not only affect female but also male members of the narrow family group. Thus, in our study of Rwanda, we found that old parents were harassed by their boys on the ground that they had reserved for themselves more land than could be justified by their subsistence needs in old age. Despair among old people was sometimes reflected in a longing for death, or it led them to select a poor caretaker outside the family circle in order to help them work their piece of land on the understanding that he would inherit it upon their death (André and Platteau 1998).

\subsection{The diminishing role of the commons}

The role of the village commons as an institutional arrangement providing social security can decrease as a result of either their sheer physical disappearance or their reduced economic significance under the impact of population growth, possibly mitigated by growing market integration. For the sake of clarity, we consider these two distinct situations in turn.

\subsubsection{Privatization of the commons}

The first effect occurs when the commons are being privatized because the efficiency costs of a common-property regime become too high (see Baland and Platteau 1996, for a formal elaboration) and people want to complement their privately inherited lands, which have become too small, with a share of the resources that used to be jointly held in the past. Division of the commons may be made in an rather egalitarian and democratic manner or in a coercive way under the initiative of a village elite eager to appropriate them for their private benefit (see Platteau 2000: ch. 3, for more details).

In the latter instance, even allowing for the combined fact that (i) the villagers now deprived of access to the local commons may possibly be hired as labourers by the new exclusive owner; and that (ii) the privatized resource will be more efficiently managed because externalities are better internalized under private than collective ownership, the distributional consequences of privatization may be undesirable. As Weitzman (1974) has shown, indeed, dispossessed resource users are necessarily worse off after privatization when they lose the rent associated with the resource 6 This follows from the fact that the wage earned in the newly created labour market is always lower than the income obtained under communal ownership. Former resource users thus lose not only in terms of employment (not all the joint owners of the resource in the previous situation will be hired by the appropriator after it has been privatized) but also on account of reduced individual labour earnings. In point of fact, the rent collected by landlords exceeds the extra output society achieves by shifting from common property to the private ownership equilibrium (Samuelson 1974).

6 For a simple graphical proof of Weitzman's theorem under the assumption of quasi-linear preferences, see Baland and Platteau 1996, pp. 47-8. 
The result obtained by Weitzman is not quite robust, however. As a matter of fact, even without a share of the rents, it is possible that the returns to labour rise with privatization if complementary inputs to labour are variably provided (De Meza and Gould 1985, 1987). Moreover, in general equilibrium, as the output obtained in the commons is expected to fall after privatization due to better internalization of externalities, its price will increase resulting in a rise of the marginal product of labour and the real wage. The same result of increasing real wages following privatization of a commons can be achieved by assuming that workers are heterogeneous in skills (Brito et al. 1997).7 Lastly, it is noteworthy that all these arguments are static: if the exclusive owner responds to privatization by adopting technical innovations and if these innovations are labour-intensive (this assumption is purely gratuitous as we have no particular reason to believe that it would be true), the level of employment could be higher than assumed by Weitzman.

What needs to be emphasized now is the following: the above-illustrated indeterminacy in the predicted distributive outcome of privatization comes out of works that overlook the insurance role that common property resources might play, as underlined in the previous section. In order to properly assess the possible insurance gains that common property allows, it is essential to take into account the possibility that after privatization other institutions may emerge to provide similar consumption insurance. If contracting were complete, we know from general equilibrium theory that outcomes under privatization would dominate those under the common property regime. Yet, in the rural areas of developing countries, contracting is typically incomplete so that the result of the comparison between the two property regimes is not straightforward. Baland and François (1999) have recently addressed this problem rigorously by considering two sources of contracting incompleteness: the first one arises out of informational asymmetries while the second one is due to limited enforcement. In the first situation, individuals have private productivity information but contracts conditioned on commonly known events can be fully enforced. By contrast, the second situation is characterized by widely shared information about individuals but poor enforcement prevents compliance with the terms of contracts ex post.

In the presence of such contracting limitations, and a full tragedy of the commons, the authors show that if individuals face independently distributed risks and are sufficiently risk averse, privatization of the common property resource, even when perfect, costless and equitable, can reduce welfare. In other words, common property has desirable consumption insurance features which are not present under private property and 'cannot be replicated by the establishment of a private insurance market under equivalent informational assumptions' (Baland and François 1999: 3). In the first situation (private information and full enforcement), the insurance advantage of common property is all the more likely to exist as the income derived from the use of the common property is higher and the labour earning possibilities of the adversely

7 When workers are heterogeneous, indeed, institutional arrangements associated with ownership as well as the technology that creates the externality become crucial and the outcome of privatization (whether it is Pareto-improving) is highly sensitive to the particular assumptions made. More precisely, the institutional arrangements of a licensor (the private owner charges a fixed fee for the use of the fixed factor) or a two-part tariff on effort or output (a linear tax with a fixed entry fee) can lead to an increase in the income of the variable factor after privatization (since, in those cases, the owner is not able to appropriate all the gains from privatization). 
affected agents are lower. In the second, opposite situation, this advantage is all the more likely to occur as both the efficiency gains from privatization and the opportunity costs from exploiting the resource for agents of the high type (those with relatively attractive income opportunities outside the commons) are lower.

In general, one should therefore expect widespread opposition to privatization of common-property resources, except by those individuals who are able to appropriate them. Opposition may nevertheless dwindle if the cost of insurance rises so much, owing to the growing efficiency costs resulting from greater externalities, that it comes to exceed the benefit.

\subsubsection{Reduced economic significance of the commons: the distributive aspect}

A common property resource may be kept whole because it is prohibitively costly to divide, or because the community concerned wants to maintain it in that state for insurance or other purposes. In these circumstances, a significant increase in the number of rightsholders (the 'insiders') will produce two distinct effects. First, it will cause the average return from the use of the resource to fall, which may jeopardise the livelihood of the poor. The threat is all the more ominous if the resource is subject to gradual degradation over time under conditions of excessive pressure. In the second place, growing numbers of participants may erode the insurance capacity of the common property resource in the sense that the vulnerability or exposure to risk of the individuals depending on it may become larger. As for increasing market integration, it may mitigate and even outweigh the negative effect of population growth on average incomes while it is likely to fail to mitigate the negative effect of population growth on income variations. Let us now substantiate these results in greater detail.

The negative effect of population growth on average incomes obtains as soon as we assume that the resource is subject to decreasing returns, an inescapable outcome of scarcity. Consider a situation in which two income sources are available to community members: farming incomes derived from privately-held land, on the one hand, and incomes obtained from a common property resource, say a fishing space, on the other hand. To begin with, we assume that all households are equally endowed in privately held land. For the sake of simplicity, we make the additional inconsequential assumption that the two activities, farming and fishing, are exclusive in the sense that a given individual cannot be simultaneously engaged in both. All households choose the proportion of their workforce that is going to work on the commons and, since they are equally endowed, this proportion is identical across all households. Furthermore, all villagers operating on the commons are assumed to be equivalently productive and to receive the average product therefrom.

This situation is depicted in Figure 1, where the average income earned per individual, denoted by $y$, is measured along the vertical axis while the total number of individuals occupied on the common fishery, denoted by $L$, is measured along the horizontal axis. The number of individuals remaining to work on the family farms is measured residually from right to left as the distance between the initial size of the population, $L_{1}$, and $L^{*}$, the equilibrium number of individuals engaged in the common fishery in the initial situation. This initial equilibrium is derived by intersecting the downward-sloping curve AA with the upward-sloping curve BB. The curve AA describes the way the average income derived from the fishing sector falls as the number of workers involved increases. As for the curve BB, its shape reflects the fact that the marginal and also the 
Figure 1

Impact of population growth and market integration on average incomes

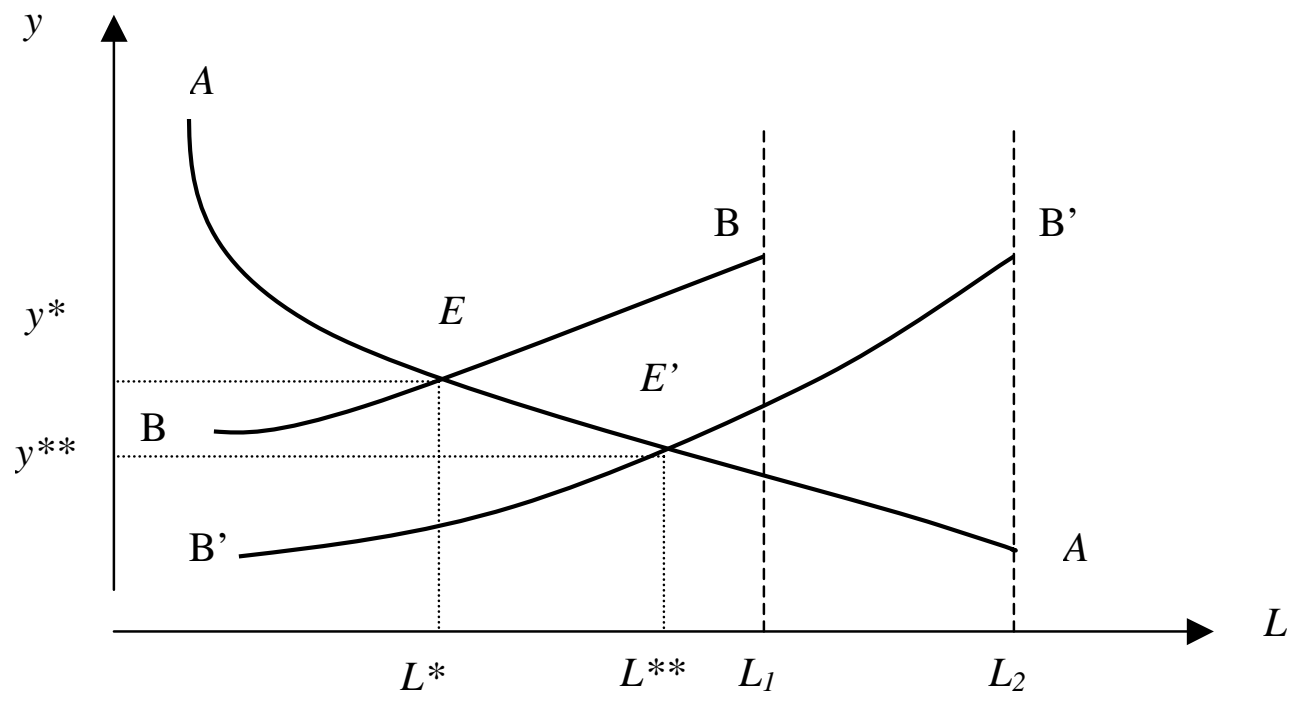

average productivity of labour in agriculture are decreasing with the number of farmers actively working the land. (For the sake of simplicity, all non-labour costs are assumed to be negligible). Corresponding to the intersection point $\mathrm{E}$ is $y^{*}$, the average equilibrium individual income in the initial situation.

Comparative statics enables us to highlight the effects of population growth and market expansion. The first effect is depicted by a shift rightwards of the perpendicular to the horizontal axis corresponding to population size, now set at $L_{2}$. As a result of this move, the upward-sloping curve shifts downwards from position BB to position B'B'. The new intersection point, E', therefore implies a lower equilibrium average individual income, $y^{* *}$, and a higher equilibrium number of people working in the common fishery, $L^{* *}$. The number of people working in agriculture has also increased, from $\left(L_{1}-L^{*}\right)$ to $\left(L_{2}-L^{* *}\right)$.

The second effect, that of market integration, may consist of an increase in the price of agricultural products that get translated in an upward shift of the BB curve. The outcome of this change is, as expected, an increase in the number of people engaged in agriculture, the sector which has become relatively more attractive, and a subsequent fall of the number of those engaged in the common fishery. Unlike what was observed in the case of population growth, the average individual income rises. If the produce collected from the commons is marketed rather than being largely self-consumed, the AA curve may also undergo an upward shift and the net change in the equilibrium number of people exploiting the common fishery will of course depend on the relative sizes of the two parallel shifts. In any event, the individual average income increases.

More interesting is the case where both population growth and market penetration occur at the same time. In such circumstances, two opposite forces are in operation and their net impact on the average individual income is impossible to predict a priori. Thus, if 
price increases affect only the agricultural sector, the curve BB undergoes a downward shift as a result of population growth and an upward shift as a result of market penetration. Bear in mind that increased rates of use of the village commons following a shift in the internal terms of trade in favour of the products extracted from them (relative to the price of agricultural products) imply a particular risk, namely that of causing their gradual degradation over time.

We may now relax the simplistic assumption according to which all community members are equally endowed in private landholdings. Adopting the formalization used by Baland and François in their aforementioned paper, let us consider a continuum of agents each of whom is endowed with one unit of labour. Each agent $i$ can allocate labour to his private farm, with returns $\theta_{i}$, or work in the common fishery. Returns to labour on the farm, $\theta$, are continuously distributed over $[0, \theta]$, by the density $f(\theta)$. The fixed amount of the common property resource is denoted by $R$ while, as above, $L$ is the aggregate labour used in the common fishery. The commons' production function, $Y(R, L)$, is homogeneous of degree one, strictly increasing and concave in $L$. It is then easy to see that an equilibrium allocation of labour in this sector is given by

$$
L^{0}: \frac{Y\left(R, L^{0}\right)}{L^{0}}=\theta^{0} \quad \text { with } \int_{0}^{\theta^{0}} f(\theta) d \theta=L^{0}
$$

With such an allocation, all agents $i$, for whom $\theta_{i} \leq \theta^{0}$, work in the common fishery and receive $Y\left(R, L^{0}\right) / L^{0}$ while all agents with $\theta_{i}>Y\left(R, L^{0}\right) / L^{0}$ work on their private landholdings obtaining payment $\theta_{i} \cdot 8$

Equilibrium allocations on the common property resource therefore imply that those villagers with smallest land endowments obtain a larger proportion of the rents generated by this resource. As pointed out by Baland and François (1999), a commons 'thus provides a form of income targeting to the poor', in line with the empirical evidence reviewed in Section 1. A presumed effect of population growth is that the absolute number of community members with $\theta_{i} \leq \theta^{0}$ increases, putting added pressure on the commons and causing a fall in the average product therefrom. The allocation of labour to the common fishery, $L^{0}$, rises in the new equilibrium and the incomes of the poor are lower. On the other hand, if it causes the value of incomes from private landholdings to rise relatively to those obtained on the common property resource, market integration reduces the pressure on this resource and the situation of the poorest members of the community improves. If prices rise in both sectors, that pressure may not be relieved, yet the poor are still better than before.

\subsubsection{Reduced economic significance of the commons: the insurance aspect}

In order to illustrate the insurance effect of the evolution of the commons, a convenient method is to posit a resource characterized by a fixed number of exploitable spots that are continuously occupied as soon as population pressure begins to bear. Think, for example, of a beachseine fishery. Beachseining is indeed a fishing technique, which

8 By assumption, the distribution of $\theta$ is such that $L^{*}>0$. Concavity of $Y($.$) in L$ ensures that the equilibrium allocation, $L^{*}$, is unique. 
requires a substantial water space located close to the shore to operate. This requirement follows from the fact that the beachseine is a large bag-shaped net with coir-wings of extensive length which, although it necessitates the help of a boat to be put out at sea, is essentially handled from the shore itself. Note that the sea bottom must be sandy and free from rocks and other obstructions so that the net can be dragged smoothly. These two constraints have the obvious effect of limiting the number of fishing spots that are available to any given coastal community (Alexander 1980, 1982, Platteau et al. 1985, Amarasinghe 1989).

Let $n$ be the number of community members who need to work on the resource to earn a living, $m$ the number of available fishing spots, $y_{i}$ the (certain) daily return yielded by spot $i$, and $\operatorname{Var}\left(y_{i}\right)$ the variance of such returns. Let us also have that $p=n / m$, the number of users per available resource spot. When $p$ exceeds one, there is a queuing problem resulting from an effective pressure of the user group on the commons. The value of $p$ can therefore be construed as a measure of the intensity of that pressure. We are essentially interested in the way household vulnerability to hunger evolves as population pressure increases. Household vulnerability, denoted by $V$, is defined here as the proportion of annual time during which the income earned by the household falls below an accepted standard of minimum consumption. It obviously varies between a minimum zero value and a maximum unitary value. Incomes are assumed to be earned on a daily basis.

Four basic cases can then be distinguished even though more complex variants are possible, as we will argue at the end.

The first case is a benchmark for assessing the second case. It obtains when $p=1$ and $\operatorname{Var}\left(y_{i}\right)=0$, that is, when all rightsholders can be continuously occupied (since there are just enough resource locations for the potential users) and returns are uniform across all fishing spots. Under such conditions, it is obvious that all resource users earn a constant income over successive periods of time since they have a guaranteed access to a fishing spot every day and the yields in all the spots are identical and certain. As a result:

$V=0$.

The second case occurs when $p>1$ and $\operatorname{Var}\left(y_{i}\right)=0$, implying that population pressure on the common fishery is brought to bear while variation in yields is still nil. Now, because there are not enough fishing locations to accommodate all the claimants in the coastal community, a rotation rule is devised so as to allow the limited locations available on each fishing day to be equally shared among them 9 An immediate effect is that members of that community are unoccupied and deprived of labour income during $(n-m) / n$ per cent of the time. In other words:

$V=1-1 / p>0$.

9 Incidentally, it is evident that $\operatorname{Var}(Y j)$, the variance of income of individual $j$, is not monotonically increasing with $p$ : as a matter of fact, this statistic will rise until it reaches a maximum value beyond which it will start to fall. 
It directly follows that $d V / d p>0$ : the vulnerability of the household rises as population pressure increases. Since $V>0$ as soon as $p>1$, an insurance problem arises when a genuine pressure on the commons manifests itself.

The third case, a benchmark for the next and most interesting case, arises when $p=1$ and $\operatorname{Var}\left(y_{i}\right)>0$. All rightsholders have continuous access to a fishing location but the daily return varies between locations. Moreover, the distribution of location-specific yields is such that the yield falls short of the minimum subsistence level, labelled $c$, in some fishing sites but not in others. In accordance with the anthropological literature, the rotation rule is assumed to provide that people should be shifted from day to day from one spot to another so that income-earning opportunities are perfectly equalized (see Baland and Platteau 1996: 199-209). In these circumstances, denoting by $F$ the relative number of fishing spots such that $y_{j}<c$, and bearing in mind that $0 \leq F \leq 1$, we have

$V=F, \quad$ with $0 \leq V \leq 1$ and $d V / d F>0$.

Finally, the fourth case obtains when $p>1$ and $\operatorname{Var}\left(y_{i}\right)>0$. This is the case analysed by Alexander in his study of beachseine fishing communities in Sri Lanka (1982) or by Berkes in his study of Alanya fishermen in Turkey: the number of claimants exceeds that of the available fishing spots and the quality of these spots varies significantly. Assuming that the same rotation rule as above is in force 10 it is evident that the daily incomes of the fishermen now vary on a double count: for one thing, there are days during which they are employed on the fishery and, for another thing, the incomes obtained during their allowed time of operation vary depending on which location they have access to. As a result, their vulnerability is larger than under the previous two cases.

The formula describing household vulnerability when the two above sources of income variability compound their effects is:

$$
V=\frac{n-(m-m F)}{n}=1-\frac{1}{p}(1-F)
$$

It is easy to see that this is a general formula encompassing all the four cases contemplated above. Indeed, $p=1$ and $F=0 \Rightarrow V=0$ (first case); $p>1$ and $F=0 \Rightarrow V=1$ $1 / p$ (second case); and $p=1$ and $F>0 \Rightarrow V=F$ (third case). Of course, in the limit case where $F=1$, household vulnerability is at its maximum, taking on the value one (irrespective of the value of $p$ ). Under the assumptions posited for the fourth case, we continue to have:

$d V / d p>0$ and $d V / d F>0$. Furthermore, $\frac{d(d V / d p)}{d F}<0$.

10 Note that, if no rotation rule exists and access to fishing locations is anarchic, welfare losses are likely to occur because fishermen will tend to flock in the most promizing spots (those with the best income prospects) while a more balanced distribution of them among the available sites would have been more socially efficient (see Platteau and Seki 2001: 397-9, for a proof). Moreover, the costs of large congregations of boats in the best locations (collisions entailing damages and injuries) will have to be borne. 
Table 1

Evolution of household vulnerability as population grows under two different assumptions regarding the variation of location-specific yields

\begin{tabular}{ccc}
\hline$n(m=4$, given $)$ & $V$ with $F=1 / 4$ & $V$ with $F=1 / 2$ \\
\hline 6 & $4 / 8$ & $8 / 12$ \\
8 & $5 / 8$ & $9 / 12$ \\
12 & $6 / 8$ & $10 / 12$ \\
\hline
\end{tabular}

In Table 1, we present a simple numerical example that illustrates the aforementioned results. We assume that $m=4$ while $n$ takes on three different values and $F$ two different ones.

If we now consider the possibility that growing population pressure on the commonproperty resource causes its gradual degradation, we must recognise the existence of a relationship of the form $F=f(p)$, with $f^{\prime}(p)>0$. The impact of population pressure on household vulnerability then includes both a direct and an indirect effect:

$\frac{d V}{d p}=\frac{(1-F)+p f^{\prime}(p)}{p^{2}} \geq 0$,

where $p f^{\prime}(p)$ corresponds to the indirect effect.

Instead of assuming that yields of the resource vary from one location to another, we could alternatively assume that yields are identical (like in the second case considered above) yet fluctuate seasonally. To the problem of unemployment is now added the risky prospect that fishermen will have their turn during the lean season when yields are uniformly low. In the aforementioned work by Alexander (1982), only 25 per cent of the beachseines thus received turns during the flush period in 1970-71. It is true that over the medium or long term incomes are expected to even out as the rotation rule ensures that every fisherman will operate his net during the flush period if a sufficiently long period is considered. In the short term, however, the pressing question remains as to how fishermen will succeed in buffering the year-to-year fluctuations in income that are the direct result of their growing numbers (Platteau 1991: 125-9).

In the most complex case, interseasonal fluctuations in yields are added to variations between locations. Household vulnerability is likely to be quite large in such circumstances in so far as there is no reason to expect that the different types of risks will cancel each other out.

A last and important remark is in order. If the expansion of market opportunities is accompanied by a process of socio-economic differentiation that is reflected in unequal asset endowments, and if rights to have turns in a rotation scheme are defined on the basis of asset units (in this instance, fishing units) rather than of household units or individuals, the rich will improve their ability to insure in the commons at the expense of the poor. Indeed, by raising the number of their turns in the sequence of access rights 
and by spreading them over the entire net cycle, the former can stabilise their incomes. The latter find themselves in the opposite situation in so far as their shares or participation rates in the sequence of net turns are more diluted than before, thereby causing an erosion of their insurance capacity. For the poor, increasing inequality has actually the same effect as population growth. This is exactly the story told by Alexander (1982) for the village of Gahävalla in south Sri Lanka (see Bardhan et al. forthcoming, for a similar story about forestries in Nepal).

Clearly, the old rotational arrangement aimed at equalizing income-earning opportunities is perverted under the joint impact of rising pressure on the resource and private accumulation strategies by the rich. When so perverted, it may quickly become inferior to the private property outcome from the standpoint of the poor.

\subsection{Increasing individualization of land tenure rights}

We have already noted (see supra, subsection 2.1) that population growth breeds exclusionary practices initiated by the strongest customary rightsholders in village societies. The gradual demise of secondary rights traditionally enjoyed by the weaker segments of the rural population (herders, old slaves, artisans, ...) and the withdrawal of rights of land occupancy for members of late-arrived kin groups are an illustration of these marginalization processes that directly reflect the growing individualization of land rights under conditions of increased land pressure. The trend towards more exclusive possession of the land is not the only manifestation of such individualization, however. Two other ingredients that are especially relevant to our topic are (i) the increasingly permanent use rights that individual possessors enjoy over the land; and (ii) the enlarging scope of their rights to transfer it relatively freely. They are both mentioned in the following statement of Robert Bates who draws a pessimistic picture of their effects on social security:

membership in the community is no longer sufficient to guarantee access to land; nor is it a necessary condition. Thus, land can be alienated to persons outside the community. Moreover, land that is not in use does not revert to the community; it can be held for purposes of speculation, transferred to other private individuals, or bequeathed to persons of the owner's choosing. It is a consequence of this system, of course, that even in the presence of abundant land, people may starve for want of access to it; primary attraction of a communal system of land rights is that under similar circumstances such deaths would not occur (Bates 1984).

In the remainder of this sub-section, we will examine the claim made by Bates by looking at the impact of the two aforementioned components of tenure individualization on the effectiveness of social security via land access rules. We will then be in a position to critically assess his judgement about the 'primary attraction of a communal system of land rights', which will be done in the conclusive section.

(i) An immediate consequence of population pressure on land resources is the shortening of the fallow period. When this period becomes sufficiently short, actual cultivators are prompted to claim the continued possession of their parcels. They thereby call into question the erstwhile practice according to which the land once fallow must return to the community to be reallocated later when its fertility will have been 
naturally restored. To enforce their claim, as noted by Boserup, they may even 'wish to begin to recultivate a given plot before the normal period of fallow has elapsed... lest the cultivation right be forfeited by desuetude'. As a result, smaller amounts of land will be available for redistribution by the chief, and 'valuable land for redistribution will become available mainly when a family dies out or leaves the territory... Redistribution of land thus becomes a less important and less frequently exerted function of the chief, and in the end it disappears altogether...' (Boserup 1965: 79-81, see also Cohen 1980: $359)$.

Since less land returns periodically to the village pool, there are also fewer possibilities to adjust the endowments of community members when the need arises. The scope of the social security mechanism that operates through such adjustments is correspondingly reduced to eventually vanish when all land plots are under the permanent control of their individual possessors. Note that this tendency is accelerated when the right to plant trees and to bring other improvements to the land are being recognized since such improvements are a well-established method of enhancing tenure security and establishing private property rights (see, e.g. Bruce 1988, Noronha 1985, Robertson 1987, Besley 1995, Sjaastad and Bromley 1997, De Zeeuw 1997, Brasselle et al. forthcoming).

(ii) An important feature of indigenous land systems in sub-Saharan Africa is the existence of extremely tight restrictions on transfer rights. In particular, possessors are not allowed to alienate the land, which belongs to the community considered as a corporate entity (see supra). Land gifts and land loans may be permitted when individual use rights to specific plots are established but only provided that the donee or the loanee belongs to the same community (of common descent or residence) as the donor or the lender. As for land sales, they are strictly forbidden as a matter of principle.

As land becomes more scarce and therefore more valuable, however, customary prohibitions regarding land transfers are gradually relaxed. At one end of the spectrum, concomitantly with the establishment of more permanent rights over the land, the right to bequeath land to children is increasingly asserted. At the other end, the right to sell the land individually held remains circumscribed, although in a less strict manner than before. There are thus several steps through which prescriptions concerning land sale prerogatives evolve as land scarcity increases.

At first, any land parcel sold is redeemable by the seller as soon as he gets the wherewithal to repurchase it (see, e.g. Ault and Rutman 1979: 170). Indeed, as possession becomes more individualized, land is increasingly viewed as part of a family patrimony and it forms the substance of its social identity and prestige. As a result, it is an asset that may not be parted with: it belongs to the sphere of gifts - or, in the words of Godelier (1999), the sphere of 'inalienable possessions' - as opposed to commodity exchanges (Gregory 1982), implying that it can only be temporarily entrusted, but never really given away, to another individual or family. Moreover, sales are sanctioned only among members of the local community, since only they can be expected to keep their promise to give back the plot of land acquired if the above possibility arises.

Thereafter, sales become subject to a right of pre-emption by the seller (or his family): in the event that the present owner wants to dispose of the land purchased in the past, the land must go back to the original owner (or his family) provided that the latter is willing and able to repurchase it. If he is unwilling (say, because he has emigrated with 
his family) or unable to do so, the land may be sold but only with the approval of village elders. As a matter of fact, the elders have the responsibility to ensure that nobody within the group wants to acquire the land proposed for sale before allowing its disposal.

Finally, a stage is reached when all prohibitions fall into decay and land sales become completely free (see, e.g. Bruce 1986: 38-40, 1993: 42). When the right to sell thus includes sales to members outside the community and the individual possessor of the land does not need any approval, 'the last vestiges of general cultivation rights are lost and private property rights are complete. General rights survive only as grazing and collection rights on communal grazing areas and forests, whose soils are usually unsuitable for crop or intensive pasture production' (Binswanger et al. 1995: 2669).

It bears emphasis that allowing the land to fall into the hands of outsiders is generally a consequence of the fact that land markets are often activated through distress sales (André and Platteau 1996). As has been pointed out by Bohannan and Dalton (1962), indeed, villagers would feel bad if they were to take advantage of the plight of their neighbours or kin in order to enlarge their own farms. As indicated above, it is only under the understanding that they would immediately release the plots to the distress seller would he become able to repurchase them (at the original selling price) that farmers would accept to buy plots disposed of under duress by another member of their community.

If farmers want to make permanent acquisitions (an expected feature given the increasing scarcity of land and the necessity to undertake long-term land improvements), and if there is no hope that the distress seller can retake possession of his land in a foreseeable future, the passing of village lands into the hands of outsiders is a likely outcome. Note incidentally that distress sales are a natural way in which a land market can establish itself despite customary prohibitions. This is because such prohibitions are generally suspended in cases of emergency (Dalton 1962), and rule violations become the norm when emergency conditions tend to persist. 11

A similar evolution can be detected for land alienations through mortgaging. To begin with, what is permitted are traditional land pledges whereby a household obtains credit against temporarily foregoing the use of the land offered as a security to the lender. Upon repayment of the loan, the land is automatically redeemed to the pledgor. Revealingly, there is a common understanding that, even if the repayment is repeatedly postponed or delayed (sometimes over successive generations), ownership of the land is never transferred to the credit-giver, only the right to collect the proceeds derived from its exploitation. Later, this intrinsic right of the pledgor to retrieve his land is called into question and lenders - first discreetly and almost shamefully, then more openly - assert their willingness to set a time limit beyond which they can claim the right to keep the pledged land in full ownership (as I could observe in the highly populated district of Anloga, Ghana; or in the high value lands of the irrigation schemes of Yalogo, Burkina Faso).

11 Traditional prohibitions against land sales are more easily subverted when the land and money exchanged are in the form of gifts and counter-gifts rather than trade, as observed by Espen Sjaastad (1998) for Zambia. 
With a mortgage, the lender does not have the right to use the land offered as security but, precisely for that reason, he will be all the more keen to exercise his right to seize upon it if the debt is not cleared in due time. The main question is how long the borrower may delay his loan repayment before the threat of foreclosure becomes effective. Like in the case of land pledges, evolution towards free alienability of land assets is reflected in the shorter grace periods granted to the borrower, in the diminished role of the group in negotiating such grace periods in order to rescue him, and in the increasingly recognized right of the lender to stipulate precise terms regarding repayment conditions.

On the other hand, since the same kind of prohibitions as found in the case of land sales also traditionally applied to land mortgages, the individualization of land rights also gets reflected in the gradual relaxation of these prohibitions. Yet, given the enormous stake involved in such an evolution, it is not surprising that loans are often taken against other securities than the land itself, e.g. the security of standing crops. It may nevertheless happen, as has been observed on irrigation schemes in Burkina Faso (Yalogo region), that the credit-giver reserves to himself in the event of crop failure the right to take hold of his borrower's land if the latter is unable to return the loan after a more or less protracted span of time (Baland et al. 1998). In such circumstances, the risk of crop failure is entirely borne by the borrower and loans are ultimately secured by his land.

There is an evident rationale behind restrictions on free land sales or free land mortgaging by individual rightsholders and this rationale is based on obvious social security considerations. As a matter of fact, heads of a lineage or a family, and elders in general, are concerned that if land becomes freely disposable they will have eventually to bear the negative consequences that can follow from the granting of such a freedom. In Kenya, for instance, we learn that it is mainly elders who reject the idea of land mortgage while younger men tend to be more attracted by the prospect of ready cash and, as a result, they are more liable to have their lands foreclosed (Shipton 1988: 106, 120). 'Urgent' consumption needs which elders may well regard as luxury can easily drive young people into landlessness, whether inadvertently or not (Green 1987: 7, The Economist 21-7 January 1995: 49). Attractive but risky investment projects may have the same effect.

Once deprived of their land assets, since there is no state social security system to fall back on and since alternative employment opportunities are rare and labour markets risky, the venturesome or myopic youngsters are tempted to rely on the elders for their subsistence needs. To avoid being involved in such rescue operations, elders prefer that land sales by youngsters be made subject to their approval. In other words, restrictions on the free play of land markets eventually arise from the absence of a centralized social security mechanism as well as from all sorts of market imperfections (including risky labour markets and imperfect credit and insurance markets) that make people dependent on their native community or social group for a guaranteed livelihood.

It is interesting to point out that in Kenya (the only country in sub-Saharan Africa with several decades of experience with systematic registration and titling of rural lands), District Land Control Boards in charge of approving land sales are frequently reluctant to permit transactions which would leave families (and their descendants) landless and destitute. That is why they insist that all adult members of the household (including women) of the title-holder are to be present at the hearing to indicate their agreement with the sale. The government has actually sanctioned this de facto situation since a 
presidential directive aimed at minimizing land disputes requires the agreement of family members in addition to that of the title-holder prior to any sale or use of land as collateral (Haugerud 1983: 84, Mackenzie 1993: 200, Pinckney and Kimuyu 1994: 10).

In Zimbabwe, likewise, a proposal by a land tenure commission appointed by the government (October 1994) provides that individual farmers should be given the right to own their land, but their right to buy and sell it should be subject to the approval of the traditional village council (the sabuku) which in pre-colonial days used to be vested with the prerogative of allocating local lands (The Economist 21-7 January 1995: 49).

The lesson to draw from the above evidence is that, although there is an unmistakable trend towards the assertion of the right to permanently transfer land in African rural areas, resistance is still pervasive against unhibited land sale and mortgage transactions (see Platteau 2000: Chap. 4, for a more detailed account). This is apparently because of the social security risk involved. Revealing of the resistance that people can put up against such unfettered transactions is the fact that in Kenya lenders have had great difficulty foreclosing on land mortgages chiefly because 'the presence of many kin around mortgaged land makes it politically unfeasible to auction the holdings of defaulters' (Shipton 1988: 120). In urban peripheries, notes another study, 'although some banks have accepted titled land as collateral and auctioned it off in cases of default, in some cases purchasers were not able to take occupation of the land for fear of reprisals' (Migot-Adholla et al. 1991: 170).

In a recent study conducted in 36 villages of East-Central Uganda, probably the African country with the strongest tradition of land market activity (which dates back to colonial times), two results achieved by the authors are particularly relevant to our discussion. On the one hand, rural land markets are remarkably active as indicated by the fact that almost half of the total land area owned has been purchased. And, on the other hand, people who are native of a given location and did not inherit any land from their father have a privileged access to the local land sale market: other things being equal, they are able to purchase significantly larger areas than other residents, which enables them to eventually hold a sufficient amount of land to start a sustainable farming activity (Baland et al. 2001) 12 In addition, for autochthonous villagers with a positive land endowment inherited from the father, there is an inverse relationship between initial land endowment and the amount of land purchased in the village.

Such a positive discrimination in favour of landless or quasi-landless members of the community is mirrored in the fact that land sale transactions are typically subject to restrictions in the form of requirement of prior notification or approval by lineage authorities. Revealingly, a recent study done in the same region has concluded that 'despite the high proportion of parcels that had been acquired through purchase, the unfettered individual right of sale is relatively uncommon' (Place et al. 2001: 219). Such restrictions are usually driven by social security considerations, meaning

12 Note that in estimating the effect of landlessness on access to local land parcels offered for sale, the possibility that landless farmers expect to receive land in the future when their (presently living) father will have died has been explicitly allowed for. 
concretely that (i) land is not being sold by people who may later need it, and (ii) priority is given to land-hungry people in the disposal of the land.13

In Rwanda, unlike what has been observed in Uganda, land sale transactions have had the effect of concentrating land in the hands of a minority of people lucky enough to enjoy access to the few non-agricultural employment opportunities available (see the indepth study of André and Platteau 1998). Others, who did not have the required political connections to get access to these scarce jobs, have often been forced to resort to distress sales of land parcels in order to make ends meet. In this country, customary restrictions on land sale transactions have completely collapsed, giving rise to extremely bitter reactions on the part of landless people towards those who have purchased significant amounts of land thanks to their discriminatory access to ample nonagricultural incomes. The centrifugal tendencies operating in the Rwandan countryside are so strong that one can no more speak of 'village communities' and 'village customs', a consequence of extreme and continuing land pressure combined with an acute dearth of off-farm employment opportunities. These accumulated resentments, frustrations, and hatred manifested themselves in the crudest manner on the occasion of the 1993 civil war since there was a selective killing of large landowners even after controlling for ethnic affiliation.

The central lesson from the above two contrasted studies is therefore that rural land sale markets, provided that their functioning is limited by social security-driven considerations inspired by traditional norms, are susceptible of mitigating rather than accentuating inequalities in initial endowments. If such restrictions have vanished, on the other hand, one may fear that land sale transactions have a disequalizing impact.

It is time to recap our central argument. When a household head is allowed to sell land to another member of his community, it is because he can thus tide over a difficult period and is expected to redeem his land in the future. And it is because it wants to ensure that such repurchase will indeed be feasible that the social group does not approve land sales to people outside of its confines. Only upon its own members can it exercise the necessary pressure to prevent any reneging on the promise to give back the land purchased when the seller will be in better straits. Yet, beyond a point, presumably, land becomes such a valuable asset that promises to part with the land purchased once the seller is able to buy it again become non-credible, even when they have been made by fellow community members.

At this stage, the granting to the land seller of a pre-emption right to later repurchase his land if offered for sale constitutes the expected next step in the gradual emergence of a free land sale market. The rule according to which landless members of the community should have priority access to the local land sale market whenever a land is supplied participates in the same logic of providing whatever feasible support to deserving community members. This said, in so far as the social group does not really provide the landless or the land-hungry or the distress seller with the wherewithal needed to buy land, the above rules constitute only an imperfect mechanism. Witness to it is the fact that distress sales do occur in the first place. Incidentally, the fact that poor people sell

13 For a reason explained above, this priority is more easily given when the land sale is caused by the owner's emigration (a frequent occurrence in Uganda) or his desire to consolidate his land assets in the village than when it is caused by distress conditions. 
land under duress also attests to the imperfection of mutual insurance networks based on state-contingent reciprocal transfers, or to the presence of important aggregate risks.

\section{Conclusion}

The problem with the judgement made by Robert Bates in the beginning of this subsection is that it mistakenly assumes that the customary system of corporate land ownership can be maintained intact under changing conditions of land availability ('under similar circumstances such deaths would not occur' - my italics). It is as though such a system would be the outcome of a cultural evolution conceived as an autonomous process cut off from the sphere of material determinants of human life. We believe, on the contrary, that values, norms, and institutions are devices that answer the need to coordinate human behaviour in the specific context of a given technological, ecological, and economic environment. In other words, they are profoundly influenced by a particular set of material determinants of human life.14

Thus, as Ester Boserup (1965) and others (see, e.g. Johnson 1972: 271, Ault and Rutman 1979: 171-8) have convincingly argued, a communal system of land rights is conceivable only under conditions of relatively high land-man ratios. 15 When land becomes so scarce as to require a shift to intensive land use patterns, several processes are set in motion.

As far as common-property resources are concerned, three main evolutions are discernible. First, the growing incidence of externalities (economic and ecological) that results from increasing land scarcity has the effect of raising the cost of insurance provided through a guaranteed access to the village commons. The cost may rise so much as to exceed the benefit and rightsholders may therefore wish to divide the commons amongst themselves. This is all the more likely to happen if alternative, selfinsurance opportunities have become available to them, for example, under the form of non-agricultural incomes. Second, the growing scarcity of cultivable lands tempts powerful people or the rural elite to privately appropriate the more valuable commons at the expense of other members of the local community. Third, for non-divisible common-property resources, by accumulating capital assets functioning as entry tickets richer rightsholders are able to increase their relative share of the product flows at the expense of poorer participants, thereby perverting the old rotational arrangements.

Regarding private landholdings, three additional processes can be observed. First, as land becomes more scarce, overlapping rights tend to be denied and exclusive

14 The causal chain running from material determinants to norms, values, and institutions needs not be deterministic, however. As a matter of fact, it may well be the case that different sets of norms, values, and institutions fit in with one given set of material constraints. This corresponds to the case where there exist multiple equilibria in the social game. Under these conditions, culture does not simply reflect the constraints of material life but serves the purpose of selecting one particular equilibrium among several possible ones. It remains true, however, that the material environment plays a critical role in so far as the set of possible equilibrium positions is narrowed down under its impact.

15 Thus, 'As long as a tribe of forest-fallow cultivators has abundant land at its disposal, a family would have no particular interest in returning to precisely that plot which it cultivated on an earlier occasion. Under these conditions a family which needed to shift to a new plot would find a suitable plot, or have it allocated by the chief of the tribe' (Boserup 1965: 79). 
ownership tends to be asserted by those groups, which wield more power. In point of fact, the insurance benefit arising from the flexibility of a multiple tenure system is bound to become outweighed by the growing efficiency costs entailed by that system; especially dynamic efficiency costs (the long-term land improvements that are forsaken). Second, as the fallow period is being continuously shortened as a consequence of population pressure, there is a smaller pool of land available for (periodic) redistribution in favour of the most needy villagers. And, lastly, increasing land scarcity unavoidably causes the emergence of an enlarged scope of transfer rights. Marginalization processes duly follow unless persisting prohibitions against unfettered land sales enforced by sufficiently strong village communities operate as a countervailing force.

Yet, to the extent that rural communities do not provide unlucky members with financial resources in order to help them avoid distress sales of land assets or to repurchase lost parcels of land, they cannot be considered as an effective provider of social security: pre-emption rights of repurchase to the benefit of the previous owner can thus be ineffective. Moreover, in so far as it is deemed socially unacceptable to take advantage of the plight of neighbours and kin, land offered for sale under duress is likely to be acquired by outsiders lest the land should remain without purchaser.

All these channels through which population growth exerts its influence compound their effects to make equity and insurance considerations recede into the background. As for market integration, it can also be expected to threaten customary insurance arrangements, mainly because by making new risk diversification opportunities available, it tends to enhance the self-insurance capacity of the elite. By causing the value of land and other natural resources to grow, it also accelerates the process of land tenure individualization and possibly intensifies the pressure on the commons thereby raising the risk of their eventual degradation (if the internal terms of trade turn against the products harvested on private landholdings). Finally, the opening up of new market opportunities, by inducing the village elite to follow a path of individualist capital accumulation, may lead them to call traditional sharing norms into question and to favour asymmetrical patron-client relationships.

The central conclusion emerging from the above is that redistributive and insurance concerns are predominant in the land allocation rules applied in rural societies as long as the resulting efficiency costs are moderate or insignificant. Once efficiency costs associated with corporate ownership increase significantly following a shift from extensive to intensive patterns of land use triggered by population growth and market integration, tenure arrangements undergo a major transformation towards more individualized rights. Such a transformation implies that property rights in land are increasingly defined without regard for equity and insurance concerns.

Short of creating a full-fledged centralized social security system, which can be only a distant objective given the informal character of the agricultural sector in most poor countries, there are many things that a state can do to supplement failing village-level insurance mechanisms. In particular, it can stimulate, rather than stifle, the development of land rental markets and it can reinforce protection of the tenants in ways that are not self-defeating, in the sense of discouraging the supply of land rental contracts. It can also encourage the penetration of the market into rural areas by building up the required communication infrastructure, overcoming informational deficiencies, combating rural monopolies and state patronage in the distribution of public employment, and providing basic social services to the population. Lastly, it can intervene to actively negotiate with 
rural communities with a view to minimizing exclusionary processes, especially when they take on an ethnic dimension. There is a link between this third policy avenue and the first one mentioned above. Indeed, a good way to avoid exclusion is precisely by encouraging the granting of land to strangers under rental contracts formally backed by a state or a joint state-community agency.

\section{Bibliography}

Abraham, A., J.M. Baland and J.P. Platteau (1998), 'Groupes Informels de Solidarité dans un Bidonville du Tiers-Monde: Le Cas de Kibera, Nairobi', Non Marchand (Editions De Boeck Université, Bruxelles) No.2, pp. 29-52.

Abraham, A., and J.P. Platteau (2001), 'Two Cultural Approaches to the Problem of Women's Land Inheritance', Centre de Recherche en Economie du Développement (CRED), Department of Economics, University of Namur, Belgium, mimeo.

Agarwal, B. (1991), 'Social Security and the Family: Coping with Seasonality and Calamity in Rural India', in Ahmad, E., J. Drèze, J. Hills, and A. Sen (eds), Social Security in Developing Countries, Clarendon Press, Oxford, pp. 171-244.

Alderman, H. and C.H. Paxson (1992), 'Do the Poor Insure? A Synthesis of the Literature on Risk and Consumption in Developing Countries', Policy Research Working Papers, WPS 1008, World Bank Washington DC.

Alexander, P. (1980), 'Sea Tenure in Southern Sri Lanka', in Spoehr, A. (ed.), Maritime Adaptations - Essays on Contemporary Fishing Communities, University of Pittsburgh Press, Pittsburgh, pp. 91-111.

Alexander, P. (1982), 'Sri Lankan Fishermen - Rural Capitalism and Peasant Society', Australian National University Press, Canberra.

Amarasinghe, O. (1989), 'Technical Change, Transformation of Risks and Patronage Relations in a Fishing Community of South Sri Lanka', Development and Change, Vol.20, No.4, pp. 701-33.

Andre, C., and J.P. Platteau (1998), 'Land Relations Under Unbearable Stress: Rwanda Caught in the Malthusian Trap', Journal of Economic Behavior and Organization, Vol.34, No.1, pp. 1-47.

Atwood, D.A. (1990), 'Land Registration in Africa: The Impact on Agricultural Production', World Development, Vol.18, No.5, pp. 659-71.

Ault, D.E. and G.L. Rutman (1979), 'The Development of Individual Rights to Property in Tribal Africa', Journal of Law and Economics, Vol.22, No.1, pp. 163-82.

Baland, J.M. and J.P. Platteau (1996), Halting Degradation of Natural Resources: Is There a Role for Rural Communities?, Clarendon Press, Oxford.

Baland, J.M. and J.P. Platteau (1998), 'Dividing the Commons - A Partial Assessment of the New Institutional Economics of Property Rights', American Journal of Agricultural Economics, Vol.80, August, pp. 644-50.

Baland, J.M., D. Dubuisson and J.P. Platteau (1998), 'Dynamique des Mécanismes Informels D'assurance en Milieu Rural: Le Cas du Burkina Faso', Research Report for the General Administration of Development Cooperation, Centre de Recherche en Economie du Développement (CRED), University of Namur, Belgium. 
Baland, J.M. and P. Francois (1999), 'Commons as Insurance and the Welfare Impact of Privatization', Centre de Recherche en Economie du Développement (CRED), Department of Economics, University of Namur, Belgium, mimeo.

Baland, J.M., F. Gaspart, F. Place and J.P. Platteau (2001), 'The Distributive Impact of Land Markets in Central Uganda', Centre de Recherche en Economie du Développement (CRED), Department of Economics, University of Namur, Belgium, mimeo.

Bardhan, P., J.M. Baland, S. Das, D. Mookherjee and R. Sarkar (forthcoming), 'Household Firewood Collection in Rural Nepal: The Role of Poverty, Population, Collective Action and Modernisation', in Baland J.M., P. Bardhan, and S. Bowles (eds), Inequality, Collective Action and Environmental Sustainability, Russell Sage Foundation and Princeton University Press.

Barrows, R. and M. Roth (1989), 'Land Tenure and Investment in African Agriculture: Theory and Evidence', Land Tenure Center, LTC Paper No.136, University of Wisconsin-Madison.

Bassett, T.J. and D.E. Crummey (eds) (1993), Land in African Agrarian Systems, Madison, The University of Wisconsin Press, Wisconsin.

Bates, R.H. (1984), 'Some Conventional Orthodoxies in the Study of Agrarian Change', World Politics, Vol.26, No. 2, pp. 234-54.

Berry, S. (1984), 'The Food Crisis and Agrarian Change in Africa: A Review Essa', African Studies Review, Vol.27, No.2, pp. 59-112.

Berry, S. (1993), No Condition is Permanent - The Social Dynamics of Agrarian Change in SubSaharan Africa, University of Wisconsin Press, Madison.

Besley, T. (1995), 'Property Rights and Investment Incentives: Theory and Evidence from Ghana', Journal of Political Economy, Vol.103, No.5, pp. 903-37.

Binswanger, H.P., K. Deininger and G. Feder (1995), 'Power, Distortions, Revolt and Reform in Agricultural Land Relations', in Behrman, J., and T.N. Srinivasan (eds), Handbook of Development Economics, Vol.III, North-Holland, Amstredam pp. 2,659-772.

Bohannan, P. and G. Dalton (eds) (1962), Markets in Africa, Northwestern University Press, Evanston.

Boserup, E. (1965), The Conditions of Agricultural Growth: The Economics of Agrarian Change under Population Pressure, Allen and Unwin, London.

Brasselle, A.S., F. Gaspart and J.P. Platteau (forthcoming), 'Land Tenure Security and Investment Incentives: Puzzling Evidence from Burkina Faso', Journal of Development Economics.

Breusers, M. (2001), 'Searching for Livelihood Security: Land and Mobility in Burkina Faso', Journal of Development Studies, Vol.37, No.4, pp. 49-80.

Brito, D.L., M.D. Intriligator and E. Sheshinski (1997), 'Privatization and the Distribution of Income in the Commons', Journal of Public Economics, Vol.64, pp. 181-205. 
Bromley, D. and J.P. Chavas (1989), 'On Risks, Transactions and Economic Development in the Semiarid Tropics', Economic Development and Cultural Change, Vol.37, No.4, pp. 719-36.

Bruce, J.W. (1986), 'Land Tenure Issues in Project Design and Strategies for Agricultural Development in Sub-Saharan Africa', Land Tenure Center, LTC Paper No.128, University of Wisconsin-Madison.

Bruce, J.W. (1988), 'A Perspective on Indigenous Land Tenure Systems and Land Concentration', in Downs, R.E., and S.P. Reyna (eds), Land and Society in Contemporary Africa, University Press of New England, Hanover and London, pp. $23-52$.

Bruce, J.W. (1993), 'Do Indigenous Tenure Systems Constrain Agricultural Development?', in Bassett, T.J., and D.E. Crummey (eds), Land in African Agrarian Systems, Madison, University of Wisconsin Press, Wisconsin, pp. 35-56.

Bruce, J.W. and L. Fortmann (1989), 'Agroforestry: Tenure and Incentives', Land Tenure Center, LTC Paper No.135, University of Wisconsin-Madison.

Cohen, J.M. (1980), 'Land Tenure and Rural Development in Africa', in Bates, R.H., and M.F. Lofchie (eds), Agricultural Development in Africa - Issues of Public Policy, Praeger, New York, pp. 349-400.

Coldham, S. (1978), 'The Effect of Registration of Title upon Customary Land Rights in Kenya', Journal of African Law, Vol.22, No.2, pp. 91-111.

Cox, D. and E. Jimenez (1990), 'Achieving Social Objectives Through Private Transfers - A Review', The World Bank Research Observer, Vol.5, No.2, pp. 20518.

Cox, D. and E. Jimenez (1997), 'Coping with Apartheid: Inter-household Transfers over the Life-Cycle in South Africa', Boston College and World Bank, mimeo.

Dahlman, C.J. (1980), The Open Field System and Beyond: A Property Rights Analysis of an Economic Institution, Cambridge University Press, Cambridge.

Dalton, G. (1962), 'Traditional Production in Primitive African Economies', Quarterly Journal of Economics, Vol.76, No.3, pp. 360-78.

Dasgupta, P. (1993), An Inquiry Into Well-Being and Destitution, Clarendon Press, Oxford.

Das Gupta, M. (1987), 'Informal Security Mechanisms and Population Retention in Rural India', Economic Development and Cultural Change, Vol.36, No.1, 101-20.

De Meza, D. and J.R. Gould (1985), 'Free Access Versus Private Ownership: A Comparison', Journal of Economic Theory, Vol.36, pp. 387-91.

De Meza, D. and J.R. Gould (1987), 'Free Access Versus Private Property in a Resource: Income Distributions Compared', Journal of Political Economy, Vol.95, No.6, pp. 1,317-25.

De Zeeuw, F. (1997), 'Borrowing of Land, Security of Tenure and Sustainable Land Use in Burkina Faso', Development and Change, Vol.28, No.3, pp. 583-95.

Downs, R.E. and S.P. Reyna (eds) (1988), Land and Society in Contemporary Africa, University Press of New England, Hanover and London. 
Ensminger, J. (1990), 'Co-opting the Elders: The Political Economy of State Incorporation in Africa', American Anthropologist, Vol.92, pp. 662-75.

Fafchamps, M. (1992), 'Solidarity Networks in Preindustrial Societies: Rational Peasants with a Moral Economy', Economic Development and Cultural Change, Vol.41, No.1, pp. 147-74.

Fafchamps, M., C. Udry and Czukas, K. (1998), 'Drought and Saving in West Africa: Are Livestock a Buffer Stock?', Journal of Development Economics, Vol.55, No.2 pp. 273-305.

Gavian, S. and M. Fafchamps (1996), 'Land Tenure and Allocative Efficiency in Niger', American Journal of Agricultural Economics, Vol.78, pp. 460-71.

Godelier, M. (1999), The Enigma of the Gift, Polity Press, Cambridge.

Goldstein, M. (1999), 'Chop Time, No Friends, Intrahousehold and Individual Insurance Mechanisms in Southern Ghana', University of California, Berkeley, mimeo.

Green, J.K. (1987), 'Evaluating the Impact of Consolidation of Holdings, Individualization of Tenure, and Registration of Title: Lessons from Kenya', Land Tenure Center, LTC Paper No.129, University of Wisconsin-Madison.

Gregory, C.A. (1982), Gifts and Commodities, Academic Press, London and New York.

Hakansson, T. (1988), Bridewealth, Women and Land: Social Changes Among the Gusii of Kenya, Uppsala Studies of Cultural Anthropology, University of Uppsala.

Haugerud, A. (1983), 'The Consequences of Land Tenure Reform among Smallholders in the Kenya Highlands', Rural Africana, No.15-16, Winter-Spring, pp. 65-89.

Hecht, S., A.B. Anderson and P. May (1988), 'The Subsidy from Nature: Shifting Cultivation, Successional Palm Forests and Rural Development', Human Organization, Vol.47.

Hoff, K. (1997), 'Informal Insurance and the Poverty Trap', University of Maryland, mimeo.

Humphries, J. (1990), 'Enclosures, Common Rights, and Women: The Proletarianization of Families in the Late Eighteenth and Early Nineteenth Centuries', Journal of Economic History, Vol.50, No.1, pp. 17-42.

Hunt, D. (1996), 'The Impacts of Individual Land Titling in Mbeere, Eastern Kenya', Discussion Papers in Economics, No.01/96, University of Sussex, Brighton.

Jodha, N.S. (1986), 'Common Property Resources and Rural Poor in Dry Regions of India', Economic and Political Weekly, Vol.21, No.27, 1,169-82.

Johnson, O.E.G. (1972), 'Economic Analysis, the Legal Framework and Land Tenure Systems', Journal of Law and Economics, Vol.15, No.1, pp. 259-76.

Landauer, C. (1964), Contemporary Economic Systems - A Comparative Analysis,: J.B. Lippincott Cy, Philadelphia \& New York.

Laurent, P.J., Mathieu, P. and M. Totte (1994), 'Migrations et Accès à la Terre au Burkina Faso', Cahiers du Cidep, No.20, Louvain-la-Neuve. 
Lund, C. (1998), Land, Power and Politics in Niger - Land Struggles and the Rural Code, Lit Verlag, Hamburg.

Mackenzie, F. (1993), 'A Piece of Land Never Shrinks: Reconceptualizing Land Tenure in a Smallholding District, Kenya', in Bassett, T.J., and D.E. Crummey (eds), Land in African Agrarian Systems, Madison, University of Wisconsin Press, Wisconsin, pp. 194-221.

Matlon, P. (1994), 'Indigenous Land Use Systems and Investments in Soil Fertility in Burkina Faso', in Bruce J.W., and S.E. Migot-Adholla (eds), Searching for Land Tenure Security in Africa, Kendall/Hunt Publishing Cy, Dubuque, Iowa, pp. 41-69.

McKean, M.A (1986), 'Management of Traditional Common Lands (Iriaichi) in Japan', in National Research Council, Proceedings of the Conference on Common Property Resource Management, National Academy Press, Washingon DC, pp. 533-89.

Migot-Adholla, S.E., P. Hazell, B. Blarel and F. Place (1991), 'Indigenous Land Rights Systems in Sub-Saharan Africa: A Constraint on Policy?', World Bank Economic Review, Vol.5, No.1, pp. 155-75.

Morduch, J. (1995), 'Income Smoothing and Consumption Smoothing', Journal of Economic Perspectives, Vol.9, No.3, pp. 103-14.

Morduch, J. (1999), 'Between the Market and the State: Can Informal Insurance Patch the Safety Net?', World Bank Research Observer, Vol.14, No.2, pp. 187-207.

Noronha, R. (1985), A Review of the Literature on Land Tenure Systems in Sub-Saharan Africa, Research Unit of the Agriculture and Rural Development Department, Report No.ARU 43, World Bank, Washington DC.

Nunow, A.A. (2000), Pastoralists and Markets - Livestock Commercialization and Food Security in North-Eastern Kenya, Ph.D. Thesis, University of Amsterdam.

Pinckney, T.C. and P.K. Kimuyu (1994), 'Land Tenure Reform in East Africa: Good, Bad, or Unimportant?', Journal of African Economies, Vol.3, No.1, pp. 1-28.

Place, F., J. Ssenteza and K. Otsuka (2001), 'Customary and Private Land Management in Uganda', in Otsuka K., and F. Place (eds), Land Tenure and Natural Resource Management: A Comparative Study of Agrarian Communities in Asia and Africa, The John Hopkins University Press, Baltimore and London, pp. 195-233.

Platteau, J.P. (1991), 'Traditional Systems of Social Security and Hunger Insurance: Past Achievements and Modern Challenges', in Ahmad, E., J. Drèze, J. Hills, and A.K. Sen (eds), Social Security in Developing Countries, Clarendon Press, Oxford, pp. 112-70.

Platteau, J.P. (1992), Land Reform and Structural Adjustment in SubSaharan Africa: Controversies and Guidelines, FAO Economic and Social Development Paper No.107, FAO, Rome.

Platteau, J.P. (1996), 'The Evolutionary Theory of Land Rights As Applied to SubSaharan Africa: A Critical Assessment', Development and Change, Vol.27, No.1, pp. 29-86.

Platteau, J.P. (1997), 'Mutual Insurance as an Elusive Concept in Traditional Rural Communities', Journal of Development Studies, Vol.33, No.6, pp. 764-96. 
Platteau, J.P. (2000), Institutions, Social Norms, and Economic Development, Harwood Academic Publishers.

Platteau, J.P., J. Murickan and E. Delbar (1985), Technology, Credit and Indebtedness in Marine Fishing - A Case Study of Three Fishing Villages in South Kerala, Hindustan Publishing Co., Delhi

Platteau, J.P. and E. Seki (2001), 'Community Arrangements to Overcome Market Failures: Pooling Groups in Japanese Fisheries', in Aoki M., and Y. Hayami (eds), Communities and Markets in Economic Development, Oxford University Press, Oxford, pp. 344-402.

Popkin, S.L. (1979), The Rational Peasant: The Political Economy of Rural Society in Vietnam, University of California Press, Berkeley and Los Angeles.

Robertson, A.F. (1987), The Dynamics of Productive Relationships - African Share Contracts in Comparative Perspective, Cambridge University Press, Cambridge.

Rocheleau, D., P. Steinberg and P. Benjamin (1994), 'A Hundred Years of Crisis? Environment and Development Narratives in Ukambani, Kenya', Working Papers in African Studies, No.189, African Studies Center, Boston University.

Rocheleau, D. and D. Edmunds (1995), 'Women, Men and Trees: Gender, Power and Property in Forest and Agrarian Landscapes', World Development, Vol.25, No.8, pp. $1,351-71$.

Rodenbach, E. (1999), 'La Transformation des Droits Fonciers dans la Vallée du Fleuve Sénégal: Etude de Trois Villages', Unpublished M.A. thesis, Department of Economics, University of Namur, Belgium.

Rosenzweig, M. (1988), 'Risk, Implicit Contracts, and the Family in Rural Areas of Low-Income Countries', Economic Journal, Vol.98, No.12, pp. 1,148-70.

Samuelson, P.A. (1974), 'Is the Rent Collector Worthy of his Full Hire?', Eastern Economic Journal, Vol.1, No.1, pp. 1-7.

Schapera, I. (1943), Native Land Tenure in the Bechuanaland Protectorate, The Lovedale Press, Lovedale.

Shipton, P. (1988), 'The Kenyan Land Tenure Reform: Misunderstandings in the Public Creation of Private Property', in Downs, R.E., and S.P. Reyna (eds), Land and Society in Contemporary Africa, University Press of New England, Hanover and London, pp. 91-135.

Sjaastad, E. (1998), Land Tenure and Land Use in Zambia, As: Agricultural University of Norway, Department of Forest Science, unpublished Ph.D. Thesis.

Sjaastad, E. and D.W. Bromley (1997), 'Indigenous Land Rights in Sub-Saharan Africa: Appropriation, Security, and Investment Demand', World Development, Vol.25, No.4, pp. 549-62.

Weitzman, M. (1974), 'Free Access vs. Private Ownership as Alternative Systems for Managing Common Property', Journal of Economic Theory, Vol.8, No.2, pp. 225$34 . \S$ 